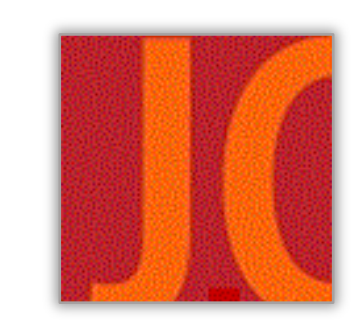

\title{
miyo waskawewin and aokakio'siit: Lessons in Learning to Walk Well
}

\author{
Lesley Tait \\ University of Calgary
}

\begin{abstract}
:
In Canada's post Truth and Reconciliation classrooms, educators continue to seek ways to begin the challenging work of lifting Indigenous knowledges within their classroom and within the curriculum. Many educators have begun to turn to land-based or place-based learning as a potential solution to this challenging work. This article undertakes a holistic dialogue with educators and offers two words, aokakio'siit, miyo waskawewin, that may serve as pedagogical reminders on how we can walk well both within the classroom and within life. This article brings together professional reflections with Indigenous teachings received from Elders, as a potential way forward in the lifting of Indigenous knowledges within schools and as a way of being in the world.
\end{abstract}

Keywords: Indigenous pedagogy; relationality; spirit, land-based pedagogy; aokakio'siit; miyo waskawewin 


\section{miyo waskawewin et aokakio'siit : des leçons pour apprendre à bien marcher}

\section{Résumé :}

Dans les salles de classe à la suite de la Commission de vérité et réconciliation du Canada, les éducatrices(teurs) continuent à chercher des moyens de commencer le difficile travail de valoriser les connaissances autochtones dans leur classe et dans le curriculum. De nombreux éducateurs ont commencé à se tourner vers l'apprentissage basé sur la terre ou sur le lieu comme solution potentielle à ce travail difficile. Cet article engage un dialogue holistique avec les éducateurs et propose deux mots, « aokakio'siit » et « miyo waskawewin », qui peuvent servir de rappels pédagogiques sur la façon dont nous pouvons bien marcher à la fois en classe et dans la vie. Cet article rassemble des réflexions professionnelles et des enseignements autochtones reçus des aînés, comme moyen potentiel de faire progresser les connaissances autochtones dans les écoles et comme moyen d'être au monde.

Mots clés : la pédagogie autochtone; la relationnalité; l'esprit; la pédagogie terrestre; aokakio'siit; miyo waskawewin 
Where words and place come together, there is the sacred.

(Momaday, 1997, p. 111)

n Canada's post-Truth-and-Reconciliation-Commission (TRC) classrooms, educators continue to seek ways to begin the challenging work of lifting Indigenous knowledges within their classroom and within the curriculum. As my contribution to these ongoing efforts, I offer the lessons that I have learned. I was born in Treaty 6 territory, to a nehiyaw (Cree) mother and settler father. I come from the Michel First Nation and am part of the Calahoo family. I spent 21 years living in this territory and learning what it meant to walk well there, learning how to conduct myself and how to pay attention. When I was 22, I moved into Treaty 7 territory and began my learning anew. Walking well here means something different.

I have driven on the Queen Elizabeth II highway between Edmonton and Calgary more times than I can count. I have driven it so early in the morning that it might still be considered night. I have driven it alone and alongside friends and family. I have driven it while listening to audiobooks and in silent contemplation. I love the drive. I consider it my transition zone. It gives me time to remember where I have come from and time to adjust again to where I am going. The drive reminds me to embody teachings from my Elders and from the two territories in which I dwell. I am still learning what the teachings from the land might mean and will continue to do so throughout my life.

With the understanding of both places, I am offering two words that I continuously revisit from my teachings: miyo waskawewin and aokakio'siit. These words help guide me as a human trying to live well in two places. These words help guide me while supporting educators who are seeking ways to better lift Indigenous knowledge systems in their classrooms. I hope that these words may also help assist you in the challenging work of including Indigenous knowledges within your classrooms and of living well as a human being in this world. Both words speak directly to pedagogical practices and both are ways of being for anyone looking to walk well in the world. The first word is nêhiyaw (Cree) and was taught to me by Elder Bob Cardinal from maskêkosak (Enoch Cree Nation); the second word is Blackfoot and taught to me by Dwayne Donald.

miyo waskawewin

Pay attention

Walk in a good way

aokakio'siit

Pay attention

Be wisely aware

These two words have come to guide how I conduct myself, how I walk on the land, how I parent my children, how I teach in the classroom, and how I work with educators. I've taken hundreds of teachers on land-based learning walks over the past four years. We walk through the trees, across the grasses and down by the river. While there are citable learning intentions for these walks, the 
true intent is to walk alongside teachers as they begin the difficult task of recognizing the wisdom of places. We learn what it might mean to walk with both miyo waskawewin and aokakio'siit. During these walks, I also share thoughts on mythicness, aimless wandering, relationship, spirit, as well as patience and humility, which helped guide me as I learned to walk well in place.

\section{Mythicness and Aimless Wandering}

In this context journeying ... must be characterized by purposeful intent-otherwise it is nothing more than aimless wandering. It is this purposeful intention that is transformative, leading the journeyer toward shifting previously held assumptions and paradigms. (Styres, 2017, p. 88)

The land is not a mythical place. In my mind, I have come to visualize a giant pendulum. On one side of the pendulum sits the idealization of place as a larger-than-life fantasy. On the other side of the pendulum is aimless wandering. Walking with both miyo waskawewin and aokakio'siit sits somewhere in the middle. To walk in a good way, to be wisely aware, I need to be listening (Kimmerer, 2015):

His teachings (Nanabozho) remind us that on half of the truth is that the earth endows us with great gifts, the other half is that the gift is not enough. The responsibility does not lie with the maples alone. The other half belongs to us; we participate in its transformation.

(Kimmerer, 2015, p. 69)

To come to know a place, I need to be able to listen to its language. To be able to listen to its language, I need to first recognize that it is speaking. To recognize that it is speaking, I need to understand that it has knowledge that is worth sharing, that it has wisdom. In learning these things, I can let go of pre-planned lessons. It is not up to me to decide. Practicing miyo waskawewin and aokakio'siit means paying attention to the lessons being offered. The entire curriculum lives out on the land. I strive to be wisely aware of what is happening to recognize the gift and lesson being offered. Like Simpson (2014), I know that "decisions around learning are in essence an agreement between individual and the spirit world" (p. 10).

Be wisely aware

Notice the cycles

The myriads of relationships

To hear the stories that live in place You need to know the place Then you can learn from them

Learn their names Greet them Notice their teachings 


\section{Relationship and Spirit}

For Siksikáitapiiksi, these places are not simply piles of rocks, cliff, or glacial erratics; they are places imbued with meaning and history. These places are the equivalent of books, encyclopaedias, libraries, archives, crypts, monuments, historical markers, and grottos. . . For students to learn about these places and from them, they needed to visit the sites rather than tour them. ... A visit holds an expectation that one will spend time, be amicable and relaxed, stay a while, be a guest, converse and probably eat a meal and drink a cup of tea. (Chambers \& Blood, 2009, pp. 260-268)

In learning to walk with miyo waskawewin and aokakio'siit, I have come to realize the importance of relationality. In each place where I have lived and worked, I have had to build relationships over time. I have had to come to know the names of the relatives who lived with me in these places. I've had to stay awhile. "Like a stranger, they will not sit down and tell you everything immediately," Little Bear says. "Only when the rocks begin to know you will they tell you their story." (as quoted by Hill, 2008, p. 42). It is this relationality that I have found to be the most beneficial in helping me to spot those lessons being offered. For example it's only with relationship that I am able to notice the changes in the land, such as the subtle shifts that occur from moon to moon. Without this type of wise awareness, I would only be able to say how pretty the moon is. Only when I have known the land, have I been able to hear its stories or understand the gifts being offered. So, I walk the land. I stay awhile. I walk the land again. And again.

Once I have built relationships with these places, I can more fully recognize their spirits. Each place has its own rhythms, its own topics, its own time, its own cyclical movement, its own flux and flow (Little Bear, 2009). Each place has its own medicines, its own stories, and its own lessons to teach. Listening to Leroy Little Bear (2000), I understand that "there [really] is no animate/inanimate dichotomy. Everything is more or less animate. Consequently, Aboriginal languages allow for talking to trees and rocks, an allowance not accorded in English. If everything is animate, then everything has spirit and knowledge" (p. 78). This reminds me to recognize the spiritual nature of the relationship in which I have engaged. Walking in this way, in these places, teaches not only my mind but also my spirit. Walking in this way teaches me what it means to be a human here, in this place, in this time.

Look, horsetail

Good medicine for your hair and nails

Made mostly of silica

It's prehistoric

It's seen the dinosaurs

Green, even in the winter A lone bright spot sticking up through the snow

Look at the buffalo berry today

It buds in such a unique way 
It's different on maskêkosihk

Taller maybe

Narrower leaves

A bit bushier

You wouldn't know if you haven't visited with both

\section{Patience and Humility}

A gift comes to you through no action of your own, free, having moved toward you without you beckoning. Your only role is to be open-eyed and present. Gifts exist in the realm of humility and mystery. (Kimmerer, 2015, pp. 43-44)

Teaching and living while practicing miyo waskawewin and aokakio'siit requires me to be patient. Patience does not come easily to me. I felt great discomfort the first time I was asked by an Elder to sit quietly in place for an extended period of time. I had become so accustomed to the fast pace and, multi-tasking life that this act of quiet contemplation in place seemed nearly impossible. And yet, each time I returned to sit in place, I began to feel myself awaken. I began to notice the lessons being offered. I learned to step aside, relinquish my teacherness, and allow the land to speak.

I have also had to learn to approach teaching and living in this way, with miyo waskawewin and aokakio'siit, with a great sense of humility. Elder Bob Cardinal has said time and time again, "I am no one and I know nothing" (personal communication). It's not that I truly know nothing, but rather that I've had to learn to be quiet, to let the land speak, to let wisdom show up. My role is not always a speaking part.

The curriculum lives out here The math, the science, the language

It's all here

But you need to be listening to it

Pay attention

Come often

Visit

iitao'tsstoyi

When the cold comes

Have you been paying attention?

You can feel the change

The wolf cap snow

Did you notice the geese?

And what about beaver?

okonokistsi otsitsi'tssp

When the saskatoons are ripening

Have you been paying attention? 
A time marked by ceremony It's not up to us to decide

The berries will tell us

\section{An Ending of Sorts}

If we listen, first, to the sounds of an oral language - to the rhythms, tones, and inflections that play through the speech of an oral culture-we will likely find that these elements are attuned, in multiple and subtle ways, to the contour and scale of the local landscape, to the depth of its valleys or to the open stretch of its distances, to the visual rhythms of the local topography. (Abram, 1997, p. 140).

Walking with miyo waskawewin and aokakio'siit goes beyond the momentary awe that one experiences when walking through a forest (Michell, 2018). It goes beyond merely appreciating beauty. Teaching and living within this Indigenous pedagogical practice has required me to move beyond a solely intellectual approach to the notion of being in the world. It has required me to think deeply about attention and intention, relationship, spirit, patience and humility. This practice has required me to engage in an ongoing conversation and build a sustained relationship with places where I live and teach. It is through the holistic embodiment of both miyo waskawewin and aokakio'siit that I am learning to walk well.

\section{About the Author}

Lesley Tait is an educator and a PhD student at the Werklund School of Education, University of Calgary. She is passionate about story and place in all its many forms and its connection to how we relate to both each other and the land. Lesley is a member of Michel First Nation and thrilled to be the mother to two wonderful daughters who continue to amaze and delight.

\section{References}

Abram, D. (1997). The spell of the sensuous: Perceptions and language in a more-than-human world. Vintage.

Chambers, C. M., \& Blood, N. J. (2009). Love thy neighbour: Repatriating precarious Blackfoot sites. International Journal of Canadian Studies, 2009(39-40), 253-279. https://doi.org/10.7202 /040832ar

Hill, D. (2008, September 1). Listening to stones: Learning in Leroy Little Bear's laboratory: Dialogue in the world outside. Alberta Views. https://albertaviews.ca/listening-to-stones/

Kimmerer, R. W. (2015). Braiding the sweetgrass: Indigenous wisdom, scientific knowledge and the teaching of plants. Milkweed.

Little Bear, L. (2000). Jagged worldviews colliding. In M. Battiste (Ed.), Reclaiming Indigenous voice and vision (pp. 77-85). University of British Columbia Press.

Little Bear, L. (2009). Naturalizing Indigenous knowledge [Synthesis paper]. Aboriginal Learning Knowledge Centre. 
Michell, H. J. (2018). Land-Based education: Embracing the rhythms of the Earth from an Indigenous perspective. J. Charlton.

Momaday, N. S. (1997). The man made of words: Essays, stories, passages. St. Martin's Press.

Simpson, L. (2014). Land as pedagogy: Nishnaabeg intelligence and rebellious transformation. Decolonization: Indigeneity, Education \& Society, 3(3), 1-25.

Styres, S. (2017). Pathways for remembering and recognizing Indigenous thought in education: Philosophies of Ienthi'nihstenha Ohwentsia'kekha (Land). University of Toronto Press.

Truth and Reconciliation Commission of Canada. (2015). Final report of the truth and reconciliation commission of Canada. Volume one: Summary. Honouring the truth, reconciling the future. James Lorimer. 